\title{
Maternal recognition of pregnancy in the rabbit
}

\author{
Romana A. Nowak and Janice M. Bahr \\ Department of Animal Science, Animal Genetics Laboratory, University of Illinois, Urbana, \\ Illinois 61801, U.S.A.
}

\begin{abstract}
Summary. Conceptuses were removed by extrusion through incisions in the uterus on Days 11,12 and 18 post coitum (p.c.). Pseudopregnant does at Days 11 and 12 and pregnant does at Day 18 were sham-operated and served as controls. Blood samples were collected before and daily for 3 days after conceptus removal. Serum progesterone profiles of does whose conceptuses were removed on Day 11 p.c. were identical to those of intact pseudopregnant and sham-operated pseudopregnant controls. Conceptus removal on Days 12 or 18 p.c. resulted in a precipitous decline $(P<0.01)$ in progesterone levels within $48 \mathrm{~h}$. LH levels were low $(<1 \mathrm{ng} / \mathrm{ml})$ in all groups before and after surgery and there were no significant differences between treated and control rabbits. These data demonstrate that the maternal recognition of pregnancy occurs by Day 12 of gestation and that conceptus removal does not result in an alteration in serum LH levels.
\end{abstract}

\section{Introduction}

The precise time at which maternal recognition of pregnancy occurs in the rabbit has not been identified. The corpus luteum of the pregnant doe requires the presence of the conceptus during the second half of gestation to maintain progesterone production for the normal length of pregnancy (Chu, Lee \& Yau, 1945; Porter, Becker \& Csapo, 1968; Holt \& Ewing, 1974; Lanman \& Thau, 1979). The rabbit placenta itself does not synthesize progesterone (Wilson \& Siiteri, 1973; Holt \& Ewing, 1974; Thau \& Lanman, 1974). Browning \& Wolf (1981) demonstrated that dependence on the conceptus develops between Days 10 and 18 of gestation. Lanman \& Thau (1979) showed that treatment with oestrogen or anterior pituitary extracts prevents luteal regression following removal of the fetal placenta on Day 18 of pregnancy and concluded that the fetal placenta synthesizes a substance which is biologically similar to one of the anterior pituitary hormones or has a stimulatory effect on the pituitary.

The purposes of the present study were (1) to identify the day on which maternal recognition of pregnancy occurs in the rabbit; and (2) to determine whether removal of the conceptus causes a change in serum LH concentrations.

\section{Materials and Methods}

\section{Animals}

Virgin New Zealand or California does weighing 4.0-5.0 kg were used. Rabbits were housed individually in a temperature- and light-controlled building, with 14L:10D (lights on 06:00 h). Pregnancy was induced by mating oestrous does twice to bucks of proven fertility. Pseudopregnancy was induced by injecting (i.v.) oestrous rabbits with 50 i.u. hCG (Ayerst Laboratories, New 
York, U.S.A.). The day of mating or day of injection was designated as Day 0 of pregnancy or pseudopregnancy, respectively.

\section{Experimental design}

Conceptuses were removed from 5 or 6 does on Days 11,12 and 18 post coitum (p.c.). Animals were anaesthetized with an i.m. injection of ketamine hydrochloride, $44 \mathrm{mg} / \mathrm{kg}$ (Bristol Laboratories, Syracuse, NY, U.S.A.) and acepromazine maleate, $0.5 \mathrm{mg} / \mathrm{kg}$ (Ayerst). Ovaries and uterine horns were exposed through a mid-ventral incision and the number of corpora lutea (CL) and fetuses was recorded. Small longitudinal incisions were made along the antimesometrial walls of the uterine horns at the implantation sites. Exposed fetuses were extruded with gentle digital pressure and fetal placentas were removed by gently peeling them from the endometrium.

The controls for the pregnant does on Days 11 and 12 were pseudopregnant does, 5 on Day 11 and 5 on Day 12. These animals were operated on in the same manner as the pregnant animals. Incisions were evenly spaced along the antimesometrial walls of the uterine horns in a number equal to the number of CL. Pseudopregnant does were used as controls to determine whether removal of conceptuses from pregnant does would result in CL function similar to that occurring in pseudopregnancy. In addition, 5 intact pregnant animals were bled daily for measurement of progesterone and LH concentrations during normal gestation. The controls for the Day-18pregnant does were 5 Day-18-pregnant rabbits in which small evenly spaced incisions were made along the antimesometrial walls of the uterine horns; these animals were allowed to litter. On the day of surgery and daily for 3 days, between $08: 00$ and $09: 00 \mathrm{~h}$, animals were bled via the marginal ear vein. Blood samples were allowed to clot overnight at $4^{\circ} \mathrm{C}$. The serum was removed and stored at $-20^{\circ} \mathrm{C}$ until assayed for progesterone and $\mathrm{LH}$.

Assays

Progesterone. Progesterone was measured by the specific RIA described and validated previously (Bahr, Gardner, Schenck \& Shahabi, 1980). Progesterone was extracted from serum before assay with petroleum ether. The extraction efficiency was monitored by the addition of $\left[{ }^{3} \mathrm{H}\right]$ progesterone and the mean recovery was $82 \%$. The progesterone antiserum obtained from $\mathrm{Dr}$ O. D. Sherwood (GS-253) was generated against progesterone-11-hemisuccinate:BSA. The antiserum cross-reacts $22 \%$ with $11 \alpha$-hydroxyprogesterone and $<1 \%$ with other steroids. The lower limit of sensitivity for the assay was $25 \mathrm{pg}$ per tube. The intra- and interassay variations were $6 \cdot 2 \%$ and $12.3 \%$, respectively.

$L H$. An homologous rabbit $\mathrm{LH}$ assay was used. The iodination preparation was rabbit $\mathrm{LH}$ (AFP-559-B) obtained from Dr A. F. Parlow, University of California, Los Angeles, CA. The procedure used for iodination of rabbit $\mathrm{LH}$ was a modification of the method of Greenwood, Hunter \& Glover (1963). Briefly, 1.0 mCi Na ${ }^{125}$ ( New England Nuclear, Boston, MA, U.S.A.) was added to $2.5 \mu \mathrm{g}$ rabbit LH in $50 \mu 10.5 \mathrm{M}$-phosphate buffer (pH 7.5). The reaction was initiated by the addition of $10 \mu \mathrm{l}$ chloramine-T solution $(250 \mathrm{mg} / 100 \mathrm{ml} 0.05 \mathrm{M}$-phosphate buffer). After $1 \mathrm{~min}$ and $45 \mathrm{sec}, 100 \mu \mathrm{l}$ sodium metabisulphite $(62.5 \mathrm{mg} / 100 \mathrm{ml} 0.05 \mathrm{M}$-phosphate buffer) were added, followed by $50 \mu 11 \% \mathrm{KI}$. Labelled hormone was purified by gel filtration on Sephadex G-75.

The procedure used in the double-antibody radioimmunoassay was similar to that reported by Niswender, Reichert, Midgley \& Nalbandov (1969), except that ${ }^{125}$ I was used as the radioactive label. The anti-rabbit LH antiserum (AFP-8-1-28), at a final dilution of 1:1800 000, exhibited a mean binding of $28.3 \%$. Duplicate samples of $500 \mu 1$ serum were assayed. Rabbit LH (AFP-599-B) was used as the standard. When various volumes $(100,200,300 \mu \mathrm{l})$ of serum from ovariectomized rabbits were assayed in triplicate, the $\mathrm{LH}$ values were $2.96 \pm 0.37,2 \cdot 39 \pm 0.30$, and $2.29 \pm 0.12 \mathrm{ng} /$ $\mathrm{ml}$, respectively. Recovery of unlabelled ligand was checked by adding $0.60,1.25$, and $2.50 \mathrm{ng}$ rabbit $L H$ to $100 \mu$ serum of ovariectomized rabbits. The percentages recovered were $96.6 \pm 11.54$, $100 \cdot 8 \pm 7 \cdot 6$, and $106 \cdot 6 \pm 10 \cdot 8$, respectively. The lower limit of sensitivity for the assay was $100 \mathrm{pg}$. Inter- and intra-assay coefficients of variation were $9.7 \%$ and $8.1 \%$, respectively. 


\section{Statistics}

Data were analysed by split-plot analysis of variance using the method of Gill \& Hafs (1971). When appropriate, Student's $t$ test was employed. Differences were considered significant if $P<$ 0.05 .

\section{Results}

Serum progesterone profiles of animals whose conceptuses were removed on Day 11 p.c. were not different from those of sham-operated pseudopregnant control animals (Text-fig. 1a). However, the progesterone values of both groups were different from those of intact pregnant rabbits on Day 14 $(P<0.01$ ). When conceptuses were removed on Day 12 (Text-fig. 1b) or Day 18 (Text-fig. 1c), serum progesterone concentrations declined within $48 \mathrm{~h}$ from preoperative levels of $10-16 \mathrm{ng} / \mathrm{ml}$ to $<2.5 \mathrm{ng} / \mathrm{ml}$. The decline in serum progesterone levels occurred more rapidly in Days 12 and 18 p.c. animals with conceptuses removed than in the corresponding control animals $(P<0.01)$.

Serum LH concentrations were similar in all 3 groups (Text-figs $1 \mathrm{a}, \mathrm{b}, \mathrm{c}$ ). There were no significant changes in LH levels over time for any of the groups.

The mean number of CL per rabbit did not differ between pseudopregnant or pregnant rabbits or between treated and intact control rabbits. Moreover, treated and intact control rabbits had the same number of conceptuses.

\section{Discussion}

Our significant findings are that maternal recognition of pregnancy in the rabbit occurs by Day 12 of gestation and that removal of the conceptus does not result in a change in serum LH levels. Removal of conceptuses on Days 12 or 18 p.c. resulted in a dramatic decline in serum progesterone levels to non-pregnant values within $48 \mathrm{~h}$. In contrast, removal of conceptuses on Day 11 p.c. did not cause a precipitous decline in serum progesterone levels. Rather, the levels declined at a rate similar to that seen in pseudopregnant does. At $72 \mathrm{~h}$ after surgery, progesterone levels were still within normal range for pseudopregnancy and pregnancy $(\sim 6 \mathrm{ng} / \mathrm{ml})$.

The CL of Day-11-pregnant does apparently have not as yet become dependent on the presence of the conceptus (fetus and placenta), and so removal of the conceptus results in progesterone levels similar to those of pseudopregnancy. On the other hand, the CL of Day-12-pregnant does has apparently become dependent on the presence of the conceptus. The CL of the Day-12-pregnant doe begin to regress almost immediately after removal of the conceptus; progesterone concentrations were equivalent to non-pregnant values by $48 \mathrm{~h}$ after surgery.

The day of maternal recognition of pregnancy is coincident with maximum progesterone production by the CL. After ovulation, progesterone levels increase steadily in pseudopregnant and pregnant does until Day 12 when they begin to decline in pseudopregnant does, but remain fairly constant in pregnant does until several days before parturition (Browning \& Wolf, 1981). The presence of the conceptus is necessary by Day 12 of gestation to rescue the CL of pregnancy and prevent luteal regression.

Serum LH levels from does in which the conceptuses were removed were low throughout the period of sampling and were not different from those of the controls, suggesting that the conceptus does not alter LH levels. However, the overall pattern of $\mathrm{LH}$ secretion may not be revealed by samples taken only once daily because $\mathbf{L H}$ is released in a pulsatile manner.

The serum LH levels reported here are in agreement with those reported by Osteen \& Mills (1979) for the pregnant doe. They measured an LH ovulatory surge of $\sim 12 \mathrm{ng} / \mathrm{ml}$ after which the LH levels decreased to basal values of $<1 \mathrm{ng} / \mathrm{ml}$ and remained at these levels throughout pregnancy. The LH values in the present study were low $(<1 \mathrm{ng} / \mathrm{ml})$ and similar for pregnant and pseudopregnant does. The very low levels of LH during atime of high progesterone output from the 

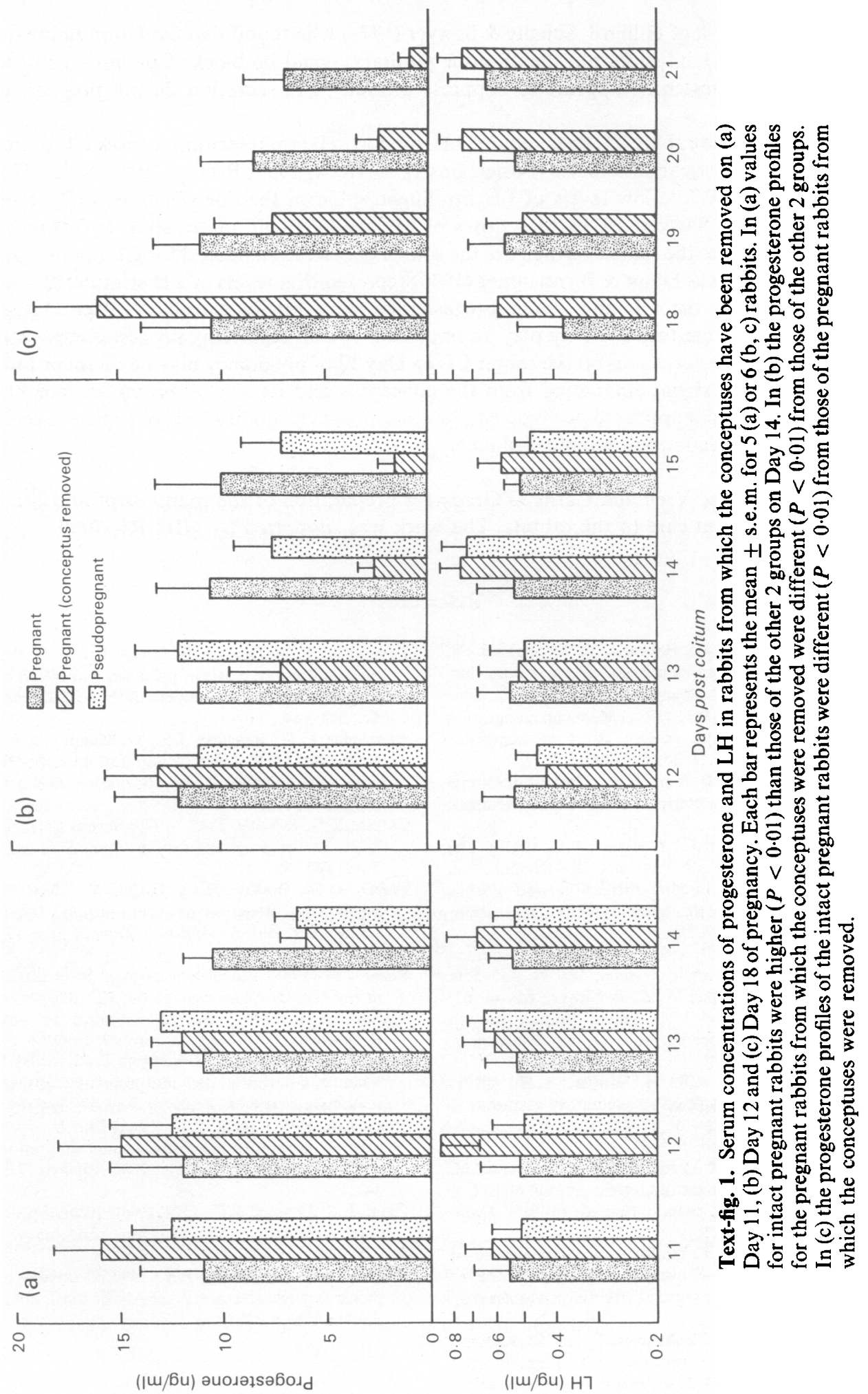
CL support the work of Hilliard, Schally \& Sawyer (1971) who found that ovulation in the doe, in response to LH-RH infusion into the anterior pituitary, could be blocked by administration of progesterone. Progesterone appears to suppress pituitary LH secretion during pregnancy and pseudopregnancy.

Nonetheless, the rabbit CL does require LH support. Hypophysectomy causes CL regression after collapse of the ovarian follicles (Foster, Foster \& Hisaw, 1937; Robson, 1947; Spies, Hilliard \& Sawyer, 1968). While low levels of LH are luteotrophic in the doe (Rennie, 1968; Hilliard, Saldarini, Spies \& Sawyer, 1971), high doses of LH are luteolytic (Stormshak \& Casida, 1965) because they ovulate the follicles which are the source of oestradiol needed for CL maintenance in the rabbit. Hunzicker-Dunn \& Birnbaumer (1976) reported that levels of LH-stimulated adenylyl cyclase activity in the $\mathrm{CL}$ and serum progesterone were highly correlated after Day 10 of pregnancy, suggesting that LH may play an important role in regulating progesterone synthesis.

The effect of the conceptus on the rabbit CL by Day 12 of pregnancy may be direct or indirect. The nature of the signal emanating from the conceptus and its site of action are not known. Although LH does not appear to be involved, the conceptus may modify FSH or prolactin secretion or synthesize a gonadotrophin-like substance.

We thank Grace Vrell and Cathy O'Grady for preparation of the manuscript and Mr Lynn Warner for excellent care of the rabbits. The work was supported by NIH RR-7030.

\section{References}

Bahr, J.M., Gardner, R., Schenck, P. \& Shahabi, N. (1980) Follicular steroidogenesis: effect of reproductive condition. Biol. Reprod. 22, 817-826.

Browning, J.Y. \& Wolf, R.C. (1981) Maternal recognition of pregnancy in the rabbit: effect of conceptus removal. Biol. Reprod. 24, 293-297.

Chu, J.P., Lee, C.C. \& Yau, S.S. (1945) Functional relation between the uterus and the corpus luteum. $J$. Endocr. 4, 392-398.

Foster, M.A., Foster, R.C. \& Hisaw, F.L. (1937) The interrelationship of the pituitary sex hormones in ovulation, corpus luteum formation and corpus luteum secretion in the hypophysectomized rabbit. Endocrinology 2, 249-259.

Gill, J.L. \& Hafs, H.D. (1971) Analysis of repeated measurements of animals. J. Anim. Sci. 31, 331-336.

Greenwood, F.C., Hunter, W.M. \& Glover, J.S. (1963) The preparation of ${ }^{131}$ I-labelled human growth hormone of high specific radioactivity. Biochem. $J$. 89, 114-123.

Hilliard, J., Schally, A.V. \& Sawyer, C.H. (1971) Progesterone blockade of the ovulatory response to intrapituitary infusion of LH-RH in rabbits. Endocrinology 88, 730-736.

Hilliard, J., Saldarini, R.J., Spies, H.G. \& Sawyer, C.H. (1971) Luteotrophic and luteolytic actions of $\mathrm{LH}$ in hypophysectomized, pseudopregnant rabbits. Endocrinology 89, 513-521.

Holt, J.A. \& Ewing, L.L. (1974) Acute dependence of ovarian progesterone output on the presence of placentas in 20-day pregnant rabbits. Endocrinology 94, 1438-1444.

Hunzicker-Dunn, M. \& Birnbaumer, L. (1976) Adenylyl cyclase activities in ovarian tissues. II. Regulation of responsiveness to $\mathrm{LH}, \mathrm{FSH}$, and $\mathrm{PGE}_{1}$ in the rabbit. Endocrinology 99, 185-197.
Lanman, J.T. \& Thau, R.B. (1979) Effect of the fetal placenta and of a rabbit pituitary extract on plasma progesterone in fetectomized rabbits. J. Reprod. Fert. 57, 341-344.

Niswender, G.D., Reichert, J.E., Jr, Midgley, A.R., Jr \& Nalbandov, A.V. (1969) Radioimmunoassay for bovine and ovine luteinizing hormone. Endocrinology 84, $1166-1173$.

Osteen, K.G. \& Mills, T.M. (1979) Serum LH and FSH levels in the pregnant rabbit. Proc. Soc. exp. Biol. Med. 162, 454-457.

Porter, D.G., Becker, R. \& Csapo, A. (1968) On the mechanism of action of intra-amniotic hypertonic saline treatment in rabbits. J. Reprod. Fert. 17, 433442.

Rennie, P. (1968) Luteal-hypophyseal interrelationship in the rabbit. Endocrinology 83, 323-328.

Robson, J.M. (1947) Recent Advances in Sex and Reproductive Physiology. Churchill, London.

Spies, H.G., Hilliard, J. \& Sawyer, C.H. (1968) Maintenance of corpora lutea and pregnancy in hypophysectomized rabbits. Endocrinology 83, 354-367.

Stormshak, F. \& Casida, L.E. (1965) Effects of LH and ovarian hormones on corpora lutea of pseudopregnant and pregnant rabbits. Endocrinology 77, 337342 .

Thau, R. \& Lanman, J.T. (1974) Evaluation of progesterone synthesis in rabbit placentas. Endocrinology 94 , 925-926.

Wilson, J.D. \& Siiteri, P.K. (1973) Developmental pattern of testosterone synthesis in the fetal gonad. Endocrinology 92, 1182-1191. 